\title{
A testképtől a testképzavarig
}

\author{
Ábrahám Ildikó dr. ${ }^{1}$ - Jambrik Máté ${ }^{1}$ - John Balázs ${ }^{2}$ \\ Németh Adrienn Réka ${ }^{2}$. Franczia Nóra ${ }^{3}$. Csenki Laura ${ }^{1}$ \\ ${ }^{1}$ Semmelweis Egyetem, Általános Orvostudományi Kar, I. Gyermekgyógyászati Klinika, \\ Gyermek- és Ifjúságpszichiátriai Osztály, Budapest \\ Fővárosi Pedagógiai Szakszolgálat ${ }^{2}$ XIV. Kerületi Tagintézménye, \\ ${ }^{3}$ VI. Kerületi Tagintézménye, Budapest
}

\begin{abstract}
Az irodalmi áttekintés célja a testkép és a testképzavarra vonatkozó szerteágazó vizsgálatok eredményeinek egységes keretbe emelése. A testkép fogalma összetett, számos aspektusból értelmezhető. A tanulmány első része kitér a testkép fejlődésének életkori sajátosságaira, a testre fókuszált figyelemre, a testnek az identitás kialakulásában játszott korai és fontos szerepére, bizonyos kamaszkori sajátságokra, a nemi különbségekre, illetve a testkép(zavar) stabilitására, amely akár egy életen átívelő vonásként is megjelenhet. A második részben a testkép szerveződése áll a fókuszban. A feldolgozási folyamatokról szóló kutatási eredmények ismertetése mellett helyet kap az érzékelés pontosságának kérdése, és az embodiment, a testi azonosulás fogalma is. Harmadik téma a testképzavar, amely először különböző kontinuumok részeként kerül kifejtésre, majd megjelenik a klinikai értelemben vett testképzavar, illetve az erre irányuló komplex vizsgálatok, a testképzavar esetleges state és trait aspektusai.

Orv Hetil. 2017; 158(19): 723-730.
\end{abstract}

Kulcsszavak: testkép, identitás, testképzavar

\section{Body image and body image distortion}

The aim of this literature review is to integrate the results of various studies regarding body image and body image distortion into a unified framework. The concept of body image is complex and can be interpreted from multiple points of view. The first part of the study touches upon different age characteristics, attentional focus on the body, the early and important role of the body in identity formation, specific features in adolescence, gender differences, and the often-observed stability of body image (distortion), which may be present as a (trait) marker throughout the lifespan. The second part focuses on the organization of body image. The results of different studies on cognitive information processing are reviewed, the question of perceptual accuracy is addressed and the concepts of embodiment are examined. The third topic is body image distortion. First, the concept is contextualized along different continua, then discussed in a clinical sense along with the complexity of diagnostic methods, as well as the state and trait aspects of body image distortion.

Keywords: body image, identity, body image distortion

Ábrahám I, Jambrik M, John B, Németh AR, Franczia N, Csenki L. [Body image and body image distortion]. Orv Hetil. 2017; 158(19). 723-730.

(Beérkezett: 2017. március 8.; elfogadva: 2017. március 30.)

Tanulmányunkban a testképre és a testképzavarra vonatkozó kurrens kutatási eredményeket foglaljuk össze klinikusi szemszögből. A témát elsődlegesen az evészavarok - azon belül is az anorexia nervosa - tükrében tekintjük át, nem térünk ki egyéb, testképzavarral járó állapotok elemzésére.

\section{A testkép fogalma és fejlődése}

A testkép fogalma az elmúlt évtizedekben sokat változott a magyar szakirodalomban. A fogalom korábbi tisztázatlansága és a pontos definíció hiánya sok esetben ellentmondást szül a tudományos közleményekben [1]. Szabó 
[1] kiemeli, hogy ez egy halványan tudatosuló jelenség, amely akkor válik explicitté, ha zavar kapcsolódik az észleléséhez. A tudományos szakirodalomban is megfigyelhető ez a jelenség: ahogy egyre több figyelmet kaptak a testképzavarok, úgy finomodott a fogalom definíciója is.

A testkép többdimenziós konstruktum, a saját testtel kapcsolatos pszichológiai élmény, amely egyszerre rendelkezik érzelmi, kognitív, viselkedéses és perceptuális sajátságokkal, emellett a testhez kapcsolódó szelférzet és viszonyulás, amely egyszerre szubjektív és szociálisan meghatározott $[2,3]$. A testkép fogalom több összetevőből áll, a személy saját testére vonatkozó perceptuális tapasztalata, a személy konceptuális tudása a testéról és az érzelmi viszonyulása a saját testéhez [4].

A testünkről való tudás igen sokrétű teljesítmény, egyszerre mentális és szomatikus eredetû, egyszerre tudatos és tudattalan természetű, egyszerre struktúra és folyamat. Tartalmát tekintve kognitív és emocionális jellegü, kialakulásának alapját a legapróbb testi mozgások és testi tapasztalatok alkotják [4].

A testkép kialakulásában szerepet játszanak szociális tanulási folyamatok, valamint a viselkedés és az érzelmek kognitív folyamatai. A testkép fejlődésére és az azzal kapcsolatos élményekre a múltbéli, fejlődési és környezeti faktorok, valamint a közvetlen események és pszichés folyamatok egyaránt hatnak [2].

A negatív testkép, a testtel való elégedetlenség és a testképzavar mélyen a gyerekkorban gyökerező jelenségek [5]. Egyre több tanulmány fogalmazza meg a pervazív jellegú, életen át tartó testképzavarok jelenségét, amelyhez sok esetben evészavarok társulnak [6]. Gyermek- és serdülőkorban a növekedéssel járó testi változások és a mozgáshoz kapcsolódó élmények, tapasztalatok mindvégig hatnak a testkép alakulására, perceptuális, kognitív, érzelmi és szociális szinten [5]. Már kora gyermekkorban meghatározó része az önértékelésnek a saját test és a megjelenés értékelése [7].

A testkép fejlődését a referenciaszerepet betöltő felnőttek (szülők, pedagógusok) és a kortárs kapcsolatokból érkező szociális összehasonlítások igen számottevően befolyásolják. A szülők hatása egyrészt az elvárások, visszajelzések mentén érvényesül, amely vonatkozhat a megjelenésre, öltözködésre és az étkezésekre is. Emellett fontos tényező a szülői modell is, a szülő viszonya a saját testéhez, az evéshez, illetve a mozgáshoz [7, 8]. A testtel, a megjelenéssel kapcsolatos megerősítő vagy elmarasztaló verbális vagy nem verbális kommunikáció, vagy az érintés egyaránt hatással van a gyermek testképének fejlődésére [9].

A testkép fejlődésében szintén igen fontos szerepet kap a szociális összehasonlítás, szociális versengés. A kortárs hatások különböző módon érvényesülhetnek, akár a súlyra és az alakra adott visszajelzéseken és megjegyzéseken keresztül, akár a test alakjáról és a testi megjelenésről szóló beszélgetések mentén, akár a súllyal kapcsolatos aggodalmak, illetve a súlycsökkentő vagy izomépítő technikák modellnyújtása által. Az elhízással kapcsolatos negatív sztereotípiák egy jelentős részét a kortársak közvetítik [7].

A fogyasztói társadalmakban fokozott a testtudatosság és a soványságkultusz. A média által közvetített túl sovány vagy túl izmos ideálok igen erőteljesen hatással vannak a gyerekek és a serdülők testképére is [10]. A testkép alakulására ható tényezők nem csupán a média különböző csatornáin (például mesefilmek), hanem játékokon (például Barbie, G. I. Joe) keresztül is érvényesülnek $[7,11]$.

A gyermekek számára is a felnőtt test az ideál, amely alapvetően meghatározza a saját testtel kapcsolatos elégedetlenséget. Már óvodáskorú gyerekeknél megjelenik az igény, hogy nagyobbak, felnőttek legyenek. A fiúk inkább izmosságra, míg a lányok vékonyságra vágynak, bár ez a nemi eltérés korántsem olyan erős még, mint serdülö- vagy felnőttkorban [11].

Már a négyéves gyerekek tisztában vannak a megjelenésre vonatkozó társadalmilag elfogadott sztereotípiákkal, megjelenik a vékony test preferenciája, a testi elégedetlenség és esetenként a tudatos fogyókúra is [12]. Ötéves lányoknál megfigyelhető a negatív testkép, az elhízástól való félelem, sőt sok esetben súlycsökkentő viselkedésformák is társulnak mindezekhez [13]. A lányok ebben az életkorban is érzékenyebbek a testre, alakra vonatkozó visszajelzésekre. A modellnyújtások (felnőtt vagy kortárs) és a testi megjelenéssel kapcsolatos kortárs kötekedések, csúfolások is nagyobb hatással bírnak a testtel való elégedetlenség kialakulására. Sok esetben az ugratások szexualizált volta tovább fokozza a testhez való negatív hozzáállást, és akár szégyenérzést is okoz [7].

A serdülőkor közeledtével, a biológiai változások következtében mindkét nemnél radikálisan megváltozik a testfelépítés, a testkép egyre nagyobb szerepet kap az önértékelésben [14]. A lányoknál hamarabb megjelenő látványos testi változások negatívan hatnak a testképre, a fizikai és az általános önértékelésre, valamint az érzelmi múködésre, amely szignifikáns különbségként jelenik meg a fiúk és a lányok között ebben az életkorban [1416]. A különbség oka - a biológiai változások mellett a társadalom, a szülők és a kortársak reakcióiban is keresendő.

A nyugati társadalmakra jellemző karcsúságideál következében a női test, a nők fizikai megjelenése nagyobb hangsúlyt kap, mint a férfiaké, gyakrabban kerül a figyelem középpontjába, megítélés alá, és sokszor válik tárgyiasítottá, ami egyértelműen negatív hatással van a serdülő lányok önértékelésére, testképére [14]. Fokozza a testképzavarok kialakulásának veszélyét az a nemi különbség is, hogy a lányok összességében több pozitív és negatív visszajelzést kapnak a testükre, testi megjelenésükre, míg a fiúk esetében a testi teljesítményük hangsúlyosabb [17]. Ezen hatások együttes eredménye, hogy a serdülő lányok egyre inkább külső szemlélőként viszonyulnak a testükhöz, amelyhez szégyen, szorongás, alacsony önértékelés és elégedetlenség társul [18]. 
A testkép alakulásában a kortársak hatása ebben az életkorban a legerőteljesebb. A serdülő lányok szignifikánsan többet beszélnek a testrôl, testsúlyról, alakról és diétázásról. A test és a megjelenés általános beszédtéma, „hájcsevej” [19] ("fat-talk” [14]) formájában is megjelenik a kortárs versengés a divatos fogyókúrák és egymás alakjának megítélésén keresztül, amelyek sok esetben a negatív testképet erôsítik $[10,14,16]$, és gyakran fordulnak át kötözködésbe, bántalmazásba [10].

A kamaszkor a fiúk esetében is számos testi változást hoz, de az igazán markáns változások csak a középső kamaszkorban tapasztalhatóak, és ezek következtében a fiúk közelebb kerülnek a társadalom által elvárt ideális férfi képéhez [13]. A serdülő fiúkra ható izmos testideál eredménye, hogy a fiúknál, férfiaknál is megjelenik és fokozódik a testtel való elégedetlenség, amely evés- és testképzavarokhoz, magatartási anomáliákhoz vagy akár önkárosító viselkedéshez vezet [20].

A hirtelen testi változásokra a környezet gyakran előbb reflektál, mint ahogy azok a serdülő számára élményszinten integrálhatóvá válnának. Így a testre kívülről érkező reflexiók (ami akár egy anorexia kulcsmondatává is válhat) elidegenítő hatásúak lehetnek. A negatív testkép és a testtel való elégedetlenség aránya mindezen testi, intrapszichés és interperszonális folyamatok következtében ugrásszerúen megnő a pubertás idején. A prepubertáskorú lányoknál 40-50\%-ra tehetô a testtel való elégedetlenség, a korai serdülőkorban ez az arány már 70\% feletti. Ehhez társul az a diszfunkcionális gondolkodás, hogy a serdülő lányok úgy vélik, ha vékonyabbak volnának, akkor egyúttal boldogabbak, egészségesebbek és vonzóbbak is lennének [16]. Ennek következtében már a korai serdülőkorban igen elterjedtek a súlycsökkentő viselkedésformák (például diétázás, purgálás), amelyek gyakran kiegészülnek falásrohamokkal, és későbbi evészavarok rizikótényezői lehetnek [14].

Longitudinális vizsgálatokban kimutatták, hogy a serdülőkori testkép stabil vonás és a testtel való elégedetlenség évekig fennmarad. A negatív testkép, a testtel való elégedetlenség olyan későbbi pszichopatológiás múködésmódok rizikófaktora, mint az evés-, szorongásos és hangulatzavarok, illetve általános önértékelési problémák, akár öngyilkossági szándék is [13, 14, 16]. A negatív testkép szignifikáns distresszként van jelen, amelynek hatása van az életminőségre, az interperszonális kapcsolatok alakulására vagy az iskolai, munkahelyi funkcionálásra [6].

\section{A testkép feldolgozási folyamatai}

A testkép fogalom komplexitása és szerteágazó értelmezése miatt nehéz a testkép és a testképzavar vizsgálata, illetve a különböző aspektusokra irányuló kutatások közös értelmezési keretbe emelése. Egyes vizsgálatok az ingerre és annak feldolgozási folyamatára, míg mások a testi reprezentációra fókuszálnak. A teljesség igénye nélkül, a klinikai szempontok alapján általunk relevánsnak ítélt kutatásokat mutatjuk be.

\section{Az A feldolgozási folyamat}

A testkép alakulására vonatkozó egyik folyamat a pillanatnyi testi érzékelésből származó információkat szervezi egységes rendszerbe, létrehozva egy folytonosan alakuló, aktuális testélményt [21]. Testünk efféle mentális leképeződéséhez legtöbbször nincsen tudatos hozzáférésünk [22]. Ezekből az adatokból azt tudjuk meghatározni, hogy az „itt és most”-ban mi a testi realitásunk [23]. A legközvetlenebb, legalapvetőbb és az egyedfejlődés során is a legkorábban múködésbe lépő forrás, amelynek révén tapasztalatot szerzünk testünkről, megéljük a létezését. Ez több érző minőséget foglal magában: bőrérzékelés, mozgásérzékelés, szervérzékelés, illetve a sokszor külön említett fájdalomérzékelés [24]. Longo és Haggard [22] ezt szomatoszenzoros érzékelésként tartja számon, és kiegészíti a metrikus paraméterek (arányok, távolságok) tudattalan érzékelésével, amelyek alapján reprezentálódik például testrészeink egymáshoz viszonyított mérete vagy szemeink, füleink távolsága, amely a térlátáshoz, illetve a hallott ingerek helyes térbeli elrendezéséhez is szükséges. Az előbbi, szomatoszenzoros érzékelés helye az elsődleges szomatoszenzoros kéreg [25]. A szakirodalomban ezt a feldolgozási folyamatot a különböző elméletalkotók más és más elnevezésekkel mutatják be. Carruthers [21] online mentális reprezentációnak [22], implicit testi reprezentációnak, Riva és mtsai [23] egocentrikus reprezentációnak nevezi. Nem szeretnénk letenni egyik elnevezés mellett sem a voksunkat, azonban a későbbi megértés szempontjából fontos elneveznünk ezt a modalitást, ezért $A$ feldolgozási folyamatnak fogjuk nevezni a továbbiakban ezt a folyamatot.

\section{A B feldolgozási folyamat}

A másik adathalmazba csoportosuló információk az „itt és most”-tól, a jelen realitásától független, időben állandó képet mutatnak arról, hogy milyennek kellene lennie a testünknek [21], ez alapján tudjuk meghatározni, hogy hol is vagyunk a külvilág elvárásaihoz viszonyítva. Ad egyfajta külső megfigyelői perspektívát, egy elvárást, hogy „milyennek kellene lennem a külvilág szerint” [23]. Sokkal inkább tudatos, hozzáférhető tudást tartalmaz saját megjelenésünkról, emellett nagyobbrészt épül komplex vizuális támpontokra [22]. Itt központi fontosságú, ám a testérzéshez viszonyítva valamivel később kibontakozó érzékelési modalitás a látás [26]. A fentiek alapján nem meglepő, hogy a látás nagyban hozzájárul ahhoz, hogy elkülönítsük magunkat a külvilágtól és másoktól, az önészlelés révén kialakuljon saját testképünk. Neuroanatómiai szempontból a testkép perceptuális komponense mögött elsősorban a posterior-parietalis cortex (PPC) múködése áll [25]. A szakirodalomban ezt a folyamatot különböző elméletalkotók szintén más és más elnevezésekkel mutatják be. Carruthers [21] offline reprezentációnak, Longo és Haggard [22] tudatos (expli- 
cit) testi reprezentációnak, Riva és mtsai [23] allocentrikus reprezentációnak nevezik. Ebben az esetben is szeretnénk függetlenek maradni, ezért ezt a modalitást $B$ feldolgozási folyamatnak fogjuk nevezni a továbbiakban.

Különböző élethelyzetek, szituációk más és más feldolgozási hangsúlyt igényelhetnek. Egy tükörbe belenézve például a vizuális támpontokra támaszkodunk elsősorban ( $B$ feldolgozási folyamat), attól eltávolodva, tükröződő felület hiányában pedig a szenzomotoros területekról származó információkat vesszük alapul ( $A$ feldolgozási folyamat). Ez egy napszak során, különböző ingerek, környezeti hatások mentén számtalanszor változhat (például, ha valaki szóvá tesz valamit rajtunk, akkor azt ellenőrizhetjük egy tükröződő felületen). Ha ezekhez a különböző élethelyzetekben nem tudunk megfelelően alkalmazkodni, akár az egyik, akár a másik információfeldolgozást erőltetjük, akkor zavar léphet fel a kognitív folyamatokban. Ez egybevág Petrucelli [27] megállapításaival, miszerint testképzavarról akkor beszélünk, hogyha az egyén szubjektív és objektív érzékelései között megszakad a kapcsolat, zavar lép fel az információáramlásban és a testkép egyensúlya sebezhetővé válik.

\section{$A z$ érzékelés pontossága}

A fentiek alapján elmondható, hogy a testérzések, illetve a vizuális információk szolgáltatják a testkép alapvető forrását. Empirikus adatok bizonyítják, hogy saját testünkkel kapcsolatos becsléseinkre különböző mértékú torzítások lehetnek jellemzőek a viszonyításhoz használt információktól függően. Longo és Haggard [22] szerint a legpontatlanabb becslések az érintéshez kötődnek. Ennek megfelelően a legdrasztikusabb testi illúziókat (többek között a végtagok megnyúlásának téves érzetét) is szenzoros ingerekkel (például vibrációval) lehet elérni [28]. Pontosabb, de még mindig torzításokat lehetővé tevő viszonyítási alapot jelentenek a metrikus információk. Ha például tárgyakhoz, vonalakhoz vagy egyéb olyan geometriai formákhoz kell viszonyítani saját testméreteinket, amely formák nem pontosan követik az emberi test formáit, hajlamosak vagyunk tévedni az arányok felmérésében. A legpontosabb becslésekre akkor vagyunk képesek, ha testrészeket vagy testeket formáló alakokat hasonlítunk össze saját testünkkel [22].

Összességében elmondható, hogy egyéni különbségek vannak abban, hogy a két információs csomagból mit és milyen arányban használunk viszonyítási pontként, ugyanis a felkínált ingerek eltérő feldolgozófolyamatokra más és más módon képesek hatni.

\section{Azonosság és rugalmasság - a testképre vonatkozó set-shifting deficit}

A feldolgozási folyamatok és azok szituatív vonatkozásai mellett alkati különbségek is szerepet játszanak a testkép feldolgozási folyamataiban.
A set-shifting (rugalmas gondolkodás, stratégiaváltás) gyengesége egy jellemző jegy evészavarokban [29]. Egyszerre rizikófaktor [29] és fenntartó tényező [30] ebben a kórképben. Jelen van gyógyult páciensekben és a páciensek testvéreiben is, utalva ezzel a genetikai befolyásoltságra [29, 31]. Klinikai megfigyelés, hogy markáns jelenléte hosszabb betegségtartammal jár együtt.

A rugalmas váltás gyengesége megjelenhet a testről való gondolkodásban is, így játszva szerepet a testképzavar kialakulásában. Ennek illusztrálásához példaként idézzük a klasszikus gumikézkísérletet [32]. A vizsgálatban részt vevő alanyok egyik karjukat az előttük lévő asztalra helyezték, egy paraván mögé, így nem láttak rá saját kezükre. Ezután egy gumikezet helyeztek az alanyok és a paraván közé, vagyis látható helyre, majd a gumikezet és a résztvevők kezét egyidejûleg simították végig egy ecsettel. A kísérleti személyek arról számoltak be, hogy az ecset érintését - amelyet valójában takarásban lévő kezükön éreztek - a gumikéz felületéhez tudták kötni, vagyis úgy élték meg, mintha a gumikéz vált volna a saját kezükké [32]. Annak mértékében, hogy mennyire érzik az alanyok sajátjukénak a gumikezet, egyéni különbségek voltak megfigyelhetőek. Magasabb szenzomotoros aktivitás volt észlelhető azoknál (nagyobb arányban használták az $A$ feldolgozási folyamatból érkező információkat), akik a leginkább bele tudtak helyezkedni a vizsgálati helyzetbe, vagyis úgy érezték, hogy a gumikéz a sajátjuk, sőt ahhoz már mozgásélmény is társult. Akiknél „csupán” a gumikéz felülete kezdett hasonlítani saját kezükéhez, kisebb szenzomotoros aktivitás volt megfigyelhető (az $A$ és a $B$ feldolgozási folyamat egyaránt beleszól). Végül azoknál, akik nem tudtak belehelyezkedni a vizsgálati helyzetbe, nagyon alacsony vagy akár teljesen gátolt szenzomotoros aktivitás volt észlelhető, vagyis nem jött létre azonosulási élmény a gumikézzel. Ők sokkal inkább építettek a látásból érkező információkra (itt a $B$ feldolgozási folyamatok vannak túlsúlyban). Ebből fontos látnunk, hogy ha az egyik információfeldolgozás túlsúlyba kerül, akkor gátolja a másik múködését [33].

\section{Embodiment (testi azonosulás)}

A saját testünkkel való azonosulás megértéséhez fontos megismernünk az embodiment (testi azonosulás) fogalmát [34]. Ez a kifejezés arra utal, hogy az ember sajátjaként éli meg testét, és tisztában van annak határaival. Ez a jelenség stabil, belső nézőponthoz kötött élmény, amelynek köszönhetően például nem keverjük össze saját kezünket valaki máséval, és amely révén képesek vagyunk meghatározni, hogyan és mely testfelülettel érintkezünk éppen a külvilággal [34]. Nagyon érdekes, ahogyan ez a belsóként megélt észlelés mégis képes elszakadni a test fizikai határaitól. A legegyszerúbb, ám annál fontosabb példa erre a tükörképünk látványa. Ahogy Povinelli [35] is rámutat, akkor is az embodiment jelenségéről beszélhetünk, amikor az önészlelés részfolyamataként felismerjük, hogy tükörképünk és saját tes- 
tünk mozgása, megélése és látványa megfeleltethető egymásnak. Saját testünkhöz kapcsolódó érzékelések és észlelések, például a testhelyzetre, a mozgásra vagy akár a nehézségre vonatkozó információk ily módon szorosan összekapcsolódnak egy külső, fizikailag tőlünk független felülettel, a tükörképünkkel. Ennek megfelelően természetes, ha a mindennapi világban a tükör vált az egyik legfontosabb visszajelzési forrássá saját testünkkel kapcsolatban. Sőt azáltal, hogy a hétköznapok során tükrözött önmagunkkal találkozunk a legtöbbször, az ismerősségi hatással [36] összhangban tükörképünket jobban kedveljük, mint testünk valódi látványát, amellyel ritkábban, például fotókon szembesülünk.

\section{Testképzavar}

\section{A testképzavar fogalma}

A testkép fogalom összetettségéből is adódik, hogy a testképzavarra sem gondolhatunk egyszerű és gyorsan változó tünetként, sokkal inkább tekinthetünk rá komplex identitásfejlődési zavar részeként, amely magában foglalja annak fizikai és szociális aspektusait [37, 38], megalapozva ezáltal az evészavarok számos tünetét, jellegzetességét. A testképzavar szerepet játszik a betegség kialakulásában [39], fenntartásában [40] és a relapsusrátában [4l], érinti a saját test alakjának, méretének elfogadásához szükséges fizikai szelf internalizációját [42], de idetartozik az alexithymia, az érzések megélésének és azonosításának zavara is. Ismert tény, hogy az éhezés a kellemetlen, distresszt okozó érzéseket tompítja [43], akár disszociatív állapotot előidézve a páciensekben („belső fájdalomcsillapító”). Ez jelezheti az embodiment zavarát vagy az $A$ feldolgozási folyamat gátoltságát. $\mathrm{Az}$ önértékelés alappillérei sokkal inkább a külső visszajelzések, mint a belső jelzőrendszer [44], ezáltal a páciensek sokkal kiszolgáltatottabbak a média hatásainak, a soványságkultusznak, sokkal erőteljesebben hatnak rájuk a referenciaszemélyektől érkező kulcsmondatok. Mindez öszszefüggésben lehet a $B$ feldolgozási folyamat túlsúlyával. A döntéshozatal nehézségei [45] és az interperszonális kapcsolatokban való elveszettség [46] szintén gyakran megfigyelhető és összefüggésbe hozható az önreflektivitás nehézségeivel anorexiás páciensek körében.

\section{A testképzavar értelmezése különböző kontinuumok mentén}

A diagnosztikus kontinuumban gondolkodva tudjuk, hogy az anorexia nervosa egyik legfontosabb magtünete a testképzavar. A test patológiás megélése azonban egyéb evészavarokban is jelen van. Gondolunk itt a bulimiára vagy a mostanában sokat emlegetett orthorexiára (egészségesétel-függőség) [47, 48]. Ez utóbbi diagnosztikus kritériumaihoz nem tartozik szorosan a testképzavar, de a klinikumban mégis sokszor látunk átfedést a két diag- nózis között. A férfiak körében elterjedt - régen inverz anorexiaként emlegetett - izomdiszmorfiában a testképzavar megélése pont fordított, az izmos férfiak soványnak látják magukat, és ez vezethet akár testépítés- vagy szteroidfüggóséghez is [20,49]. A testdiszmorfiás zavar fókuszált, lokalizált, izolált megjelenése lehet a testképzavarnak. A kórkép lényege, hogy a páciens elégedetlen egyik-másik testrészével és ez alapvetően és irreálisan befolyásolja önértékelését. Mindent megtesz azért, hogy szégyellt testrészét elrejtse vagy megváltoztassa. Gyakran ez áll a plasztikai sebészeti beavatkozások hátterében [50].

Súlyossági kontinuum egyik pólusa a patológiát nélkülöző forma. A kontinuum ezen végén van jelen az a mindenki számára ismerős élmény, amikor valaki nem ismeri fel magát fényképeken vagy nagyon idegennek érzi a róla készült fotókat, videókat. Itt tulajdonképpen a korábban tárgyalt embodiment tartós vagy átmeneti, különböző mértékű zavaráról lehet szó. Ezt provokálhatják hirtelen testi változások (például kamaszkor, várandósság). A másik pólus a pszichotikus szintű testképzavar. Konstantakopoulos és mtsai [51] kimutatták, hogy az anorexiások között mért testképzavar 28,8\%-ban téveszme súlyosságú (monoszimptómás pszichózis), és ez gyakran korai betegségkezdettel és restriktív típussal párosul.

Egy harmadik kontinuum az „én és a másik” észlelésének tengelyén képzelhető el, ahol az egyik végpont lehetne a saját test megélésének a zavara. Idetartozik a szúk értelemben vett, tiszta testképzavar, ahol a hasadás a külső szemlélő és a saját percepció, illetve megélés között van, de idesorolandó a deperszonalizáció is, ahol a hasadás a belső megélésben jelenik meg. Míg a spektrum másik vége - ami már messze túlmutat a testkép fogalmán - a misidentifikációs szindrómák, egy szignifikáns másik személy téves azonosítása köré szerveződő állapotok, ahol a másik testének, identitásának érzékelése szenved zavart. Ez utóbbi csoportba tartozik például a Capgrasszindróma, ahol a páciens úgy érzi, hogy valamelyik barátját, rokonát kicserélték, és az adott személyt imposztor helyettesíti (tehát ugyanúgy néz ki, de belül más), vagy a Fregoli-szindróma, ahol a beteg különböző személyekben véli felfedezni az üldözőjét (tehát ugyanaz belül, de nem ugyanúgy néz ki) $[52,53]$. Izgalmas vizsgálati terület lenne ezekben az esetekben a saját testtel kapcsolatos viszonyulás és testkép vizsgálata.

\section{A testképzavar mint az anorexia nervosa magtünete}

A fenti rövid kitekintés után térjünk rá az evészavarokkal együtt járó testképzavarra! Eddig a testkép szerepét az identitás vonatkozásában vizsgáltuk, most az anorexia nervosa tüneteként tárgyaljuk.

$\mathrm{Az}$ anorexiások testsúlyának rendezése a terápia igen fontos, de nem kizárólagos feladata, sok páciens érdemi, személyiségstruktúrát, kognitív elemeket és önreflexiót célzó munkára igazán csak ezt követően válik nyitottá. 
A testképzavar az utóbbi évtizedben vált mind keresztmetszetileg, mind hosszmetszetileg szélesebb körben vizsgált jelenséggé. A szakmai diskurzusban megjelent a „testsúlygyógyult” páciens fogalma, sugallva a makacsabb, elhúzódóbb tünetek (esetleges trait markerek) vizsgálatának fontosságát [54].

Az evészavar tünetei szorosan összefüggenek egymással, nehéz bármely tünetet izoláltan vizsgálni, különösen igaz ez a testképzavarra. Korábban a vizuális komponens objektivizálása volt előtérben (például Fallon-Rozinteszt, Anamorphic), illetve kérdőívekkel nézték a testtel való elégedettséget (például Eating Disorder Inventory egyik alskálája, Body Attitude Test). Az utóbbi időben a kutatások egyre komplexebbé váltak, funkcionális MRI bevonásával próbálják differenciálni és közben párhuzamosan vizsgálni mind a kognitív, mind a vizuális összetevőket, illetve testsúlygyógyult és egészséges alanyok bevonásával a stat és trait jegyek vonatkozásában is kaphatunk támpontokat. Az agy különböző régióinak funkcionális változásait akár konkrét képekkel, akár vizualizációval, akár ételre vagy testre, megjelenésre vonatkozó szavakkal, vagy szociálisan leíró melléknevekkel provokálják, de még a nézőpont váltása („,szerintem én ... vagyok”, „mások szerint én .... vagyok”) is tovább bonyolítja a kapott eredmények egymás mellé állítását. A kutatások klinikai értékelésénél azzal is számolnunk kell, hogy az eredmények átfedést mutatnak egyéb, nem szigorúan a testképhez köthető kognitív torzításokkal, gondolunk itt akár a rugalmas váltás nehézségeire (gyengült set-shifting), akár a szociális anhedoniára [29], akár az alexithymiára [55].

Az egyik irányzat képviselői a test percepciójának multiszenzoros károsodásaként [56] vagy általános szomatoszenzoros zavar részeként $[57,58]$ értelmezik a testképzavart, beleértve a taktilis, az interoceptív és a testi percepció, illetve ezek integrálásának érintettségét. Taktilis anhedoniaként [58] emlegetik azt a jelenséget, hogy a gyengéd érintést az anorexiás páciensek kevésbé érzékelik, illetve kevesebb kellemességérzést csatolnak hozzá. Az interoceptív deficit befolyásolhatja a test teljes reprezentációját, a testtudatosság alakulását [59]. Bizonyos kutatócsoportok a hangsúlyeltolódást emelik ki, amennyiben az anorexiások a testról érkező vizuális, exteroceptív jelekre jobban támaszkodnak, mint a proprioceptív információkra $[60,61]$, ezáltal sérülékenyebbé, kevésbé rezilienssé válnak a vizuális változásokkal szemben $[62,63]$. Mások inkább az ingerfeldolgozási folyamatok közti rugalmas váltást hangsúlyozzák (1. fentebb).

Míg korábban a kognitív komponens egy kevésbé vizsgált terület volt [64], ma már egyre több adat szól amellett, hogy a percepció torzulása önmagában nem elég a testképzavar kialakulásához, a kognitív és affektív eltérések (vágy a soványságra és félelem az elhízástól) elengedhetetlen faktorok $[65,66]$. Az fMRI-vel elvégzett vizsgálatok eredményei összecsengenek a tekintetben, hogy a testképzavar affektív komponense a praefrontalis ké- reghez, az insulához és az amygdalához, míg a perceptuális komponense inkább a parietalis kéreghez köthető $[64,67]$. Anorexiás csoportban ez az aktivitásfokozódás kisebb mértékű mind az önmagukra, mind a másokra irányuló percepciók esetén [68].

Az identitás szociális és testi megjelenésre vonatkozó kogníciói komplex és eltérő agykérgi aktivitással párosulnak mind egészséges, mind anorexiából gyógyultak csoportjaiban [69]. A két csoport között abban jelent meg különbség, hogy a gyógyult anorexiások esetében kevesebb szociális kognícióhoz köthető agykérgi terület aktivizálódik, mint az egészséges kontrollcsoportban, míg a testi megjelenésre vonatkozó kognícióknál ez a differencia már nem tapasztalható [69]. Ezek alapján elmondhatjuk, hogy a testsúly gyógyulása után kevésbé a fizikai megjelenés, sokkal inkább a kliens által másoknak tulajdonított szociális értékelés okoz problémát, vagyis az, hogyan vélekednek róla, milyen szociális tulajdonságokkal ruházzák fel mások. Ez az eredmény kapcsolódik az anorexiában tapasztalható mentalizációs deficitek kérdéséhez, amelyek hosszú távon lehetnek jelen.

Ez egybecseng azzal, hogy aktív anorexiások és testsúlygyógyult anorexiások összehasonlításakor a betegség aktív szakaszában megjelenik a testképzavar vizuális komponense, a fizikai megjelenésre vonatkozó kognitív disztorziók fMR-vizsgálatokkal igazolhatóak (potenciális state faktor). Ez a deficit a testsúly gyógyulásával eltűnik, de a testkép (identitás) szociális komponense hosszú távon is elmaradást mutat (potenciális trait faktor) [42]. Bár leírnak a gyógyulás során megjelenő, kompenzatórikusnak feltételezett mechanizmusokat [42].

\section{Következtetés}

A fentiekben a klinikum szempontjából általunk fontosnak vélt aspektusait emeltük ki a testkép fogalmának, életkorhoz köthető változásainak, feldolgozási folyamatai sajátosságainak, majd rátértünk a testképzavar releváns vizsgálatainak klinikai vonatkozásaira is. A testkép komplexitása révén mindenképpen izgalmas kutatási terület, terápiás hozadékai is számottevőek, emellett fontos szerepet játszhat mind az elsődleges, mind a másodlagos, mind a harmadlagos prevencióban is.

Anyagi támogatás: A közlemény megírása anyagi támogatásban nem részesült.

Szerzôi munkamegosztás: Á. I., Cs. L., J. M., J. B.: Az irodalmi háttér elemzése, a közlemény szövegének megfogalmazása. N. A., F. N.: Az összefoglaló közlemény kritikai olvasata, annak tartalmi és stilisztikai javítása. A cikk végleges változatát valamennyi szerző elolvasta és jóváhagyta.

Érdekeltségek: A szerzőknek nincsenek érdekeltségeik. 


\section{Irodalom}

[1] Szabó, P.: Body image and body outline. [Testkép és testvázlat.] In: A táplálkozási magatartás zavarai: az anorexia nervosa és a bulimia nervosa. (Eds.: Túry, F., Szabó, P.) Medicina Könyvkiadó, Budapest, 2000, 59-76. [Hungarian]

[2] Cash, T. F.: Cognitive-behavioral perspective on body image. In: Body image. A handbook of science, practice and prevention. (Eds.: Cash, T. F., Pruzinsky, T.) Guilford Press, New York, 2011, 39-48.

[3] Czeglédi, E., Urbán, R., Rigó, A.: Obesity and body dissatisfaction. [Az elhízás és testképpel való elégedetlenség.] Magyar Pszichológiai Szemle, 2009, 64(2), 313-336. [Hungarian]

[4] Gallagher, S. Cole, J.: Body image and body schema in a deafferented subject. J. Mind Behavior, 1995, 16(4), 369-389.

[5] Grogan, S.: Body image. Understanding body dissatisfaction in men, women, and children. Routledge, London and New York, 2008

[6] Hughes, E. K., Gullone, E.: Emotion regulation moderates relationships between body image concerns and psychological symptomatology. Body Image, 2011, 8(3), 224-231.

[7] Smolak, L.: Body image development in children. In: Body image. A handbook of theory, research, and clinical practice. (Eds. Cash, T. F., Pruzinsky, T.) Guilford Press, New York, 2002, 6574.

[8] Carlson-Jones, D.: Interpersonal and familial influences on the development of body image. In: Body image. A handbook of science, practice and prevention. Eds.: Cash, T. F., Pruzinsky, T. Guilford Press, New York, 2011, 110-118.

[9] Kearney-Cooke, A.: Familial influences on body image development. In: Body image. A handbook of theory, research, and clinical practice. (Eds.: Cash, T. F., Pruzinsky, T.) Guilford Press, New York, 2002, 99-107.

[10] Bird, E. L., Halliwell, E., Diedrichs, P. C., et al.: Happy being me in the UK: A controlled evaluation of a school-based body image intervention with pre-adolescent children. Body Image, 2013, 10(3), 326-334.

[11] Smolak, L.: Body images development in childhood. In: Body image. A handbook of science, practice and prevention. (Eds.: Cash, T. F., Pruzinsky, T.) Guilford Press, New York, 2011, 6775 .

[12] Damiano, S. R., Gregg, K. J., Spiel, E. C., et al.: Relationships between body size attitudes and body image of 4 -year-old boys and girls, and attitudes of their fathers and mothers. J. Eat. Disord., 2015, 3, 16

[13] Ricciardelli, L. A., McCabe, M. P.: Children's body image concerns and eating disturbance: a review of the literature. Clin. Psychol. Rev., 2001, 21(3), 325-344.

[14] Levine, M. P., Smolak, L.: Body image development in adolescence. In: Body image. A handbook of theory, research, and clinical practice. (Eds.: Cash, T. F., Pruzinsky, T.) Guilford Press, New York, 2002, 74-82.

[15] Knowles, A. M., Niven, A. G., Fawkner S. G., et al.: A longitudinal examination of the influence of maturation on physical self-perceptions and the relationship with physical activity in early adolescent girls. J. Adolesc., 2009, 32(3), 555-566.

[16] Wertheim, E. H., Paxton, S. J.: Body image development in adolescent girls. In: Body image. A handbook of science, practice and prevention. (Eds.: Cash, T. F., Pruzinsky, T.) Guilford Press, New York, 2011, 76-84.

[17] Frisen, A., Holmqvist, K.: What characterizes early adolescents with a positive body image? A qualitative investigation of Swedish girls and boys. Body Image, 2010, 7(3), 205-212.

[18] Abbott, B. D., Barber, B. L.: Differences in functional and aesthetic body image between sedentary girls and girls involved in sports and physical activity: Does sport type make a difference? Psychol. Sport Exerc., 2011, 12(3), 333-342.
[19] Csenki, L.: The role of self image and body image in personality development. [Az énkép és a testkép szerepe a személyiség fejlődésében.] In: Tudományos alapok a testnevelés tanításához II. (Eds.: Révész, L., Csányi, T.) Magyar Diáksport Szövetség, Budapest, 2015, 49-70. [Hungarian]

[20] Túry, F., Babusa, B.: From Adonis to Schwarzenegger. Ideals of men and civilization. [Adonisztól Schwarzeneggerig: Férfiideálok és civilizáció.] Oriold és Társai Kft., Budapest, 2012. [Hungarian]

[21] Carruthers, G.: Types of body representation and the sense of embodiment. Conscious. Cogn., 2008, 17(4), 1302-1316.

[22] Longo, M. R., Haggard, P.: Implicit body representations and the conscious body image. Acta Psychol., 2012, 141(2), 164-168.

[23] Riva, G., Gavido, S., Dakanalis, A.: The neuropsychology of self-objectification. European Psychologist, 2015, 20(1), 34-43.

[24] Bárdos, Gy.: Somatosensation and pain. [Testérzékelés és fájdalom.] In: Általános pszichológia I. (Eds.: Csépe, V., Győri, M., Ragó, A.) Osiris Kiadó, Budapest, 2007, 413-447. [Hungarian]

[25] Longo, M. R., Azanon, E., Haggard, P.: More than skin deep: body representation beyond primary somatosensory cortex. Neuropsychologia, 2010, 48(3), 655-668.

[26] Oláh, A.: Elements of psychology. [Pszichológiai alapismeretek.] Bölcsész Konzorcium HEFOP, Budapest, 2006. [Hungarian]

[27] Petrucelli, J.: Body-states, body image and dissociation: When not-me is 'not body'. Clin. Soc. Work J., 2016, 44(1), 18-26.

[28] Kammers, M. P., van der Ham, I. J., Dijkerman, H. C.: Dissociating body representations in healthy individuals: Differential effects of a kinaesthetic illusion on perception and action. Neuropsychologia, 2006, 44(12), 2430-2436.

[29] Tchanturia, K., Davies, H., Harrison, A., et al.: Altered social hedonic processing in eating disorders. Int. J. Eat. Disord., 2012, 45(8), 962-969.

[30] Steinglass, J. E., Walsh, B. T., Stern, Y.: Set shifting deficit in anorexia nervosa. J. Int. Neuropsychol. Soc., 2006, 12(3), 431-435.

[31] Roberts, M. E., Tchanturia, K., Treasure, J. L.: Exploring the neurocognitive signature of poor set-shifting in anorexia and bulimia nervosa. J. Psychiatr. Res., 2010, 44(14), 964-970.

[32] Botvinick, M., Cohen, J.: Rubber hands 'feel' touch that eyes see. Nature, 1998, 391(6669), 756.

[33] Haans, A., Kaiser, F. G., Bouwhuis, D. G., et al.: Individual differences in the rubber-hand illusion: Predicting self-reports of people's personal experiences. Acta Psychologica, 2012, 141(2), 169-177

[34] Eilan, N., Marcel, A., Bermudez, J. L.: Self consciousness and the body: An interdisciplinary introduction. In: The body and the self. (Eds.: Bermudez, J. L., Marcel, A., Eilan, N.) MIT Press, $1995,1-28$.

[35] Povinelli, D. J.: The self: Elevated in consciousness and extended in time. In: The development of the extended self in preschool children: Theory and research. (Eds.: Moore, C., Lemmon, K.) Cambridge University Press, New York, 2001, 73-94.

[36] Zajonc, R. B.: Attitudinal effects of mere exposure. J. Personality Soc. Psychol., 1968, 9(2), 1-27.

[37] Stein, K. F., Corte, C.: Identity impairment and the eating disorders: content and organization of the self-concept in women with anorexia nervosa and bulimia nervosa. Eur. Eat. Disord. Rev., 2007, 15(1), 58-69.

[38] Fairchild, H., Cooper, M.: A multidimensional measure of core beliefs relevant to eating disorders: preliminary development and validation. Eat. Behav., 2010, 11(4), 239-246.

[39] Jacobi, C., Hayward, C., de Zwaan, M., et al.: Coming to terms with risk factors for eating disorders: application of risk terminology and suggestions for a general taxonomy. Psychol. Bull., 2004, 130(1), 19-65.

[40] Lay, B., Schmidt, M. H.: Relapses in the course of anorexia nervosa. Z. Kinder Jugendpsychiatr. Psychother., 1999, 27(3), 207219. 
[41] Keel, P. K. Dorer, D. J., Franko, D. L., et al.: Postremission predictors of relapse in women with eating disorders. Am. J. Psychiatry, 2005, 162(12), 2263-2268.

[42] McAdams, C. J., Jeon-Slaughter, H., Evans, S., et al.: Neural differences in self-perception during illness and after weight-recovery in anorexia nervosa. Soc. Cogn. Affect. Neurosci., 2016, 11(11), 1823-1831.

[43] Brockmeyer, T., Holtforth, M. G., Bents, H., et al.: Starvation and emotion regulation in anorexia nervosa. Compr. Psychiatry, 2012, 53(5), 496-501.

[44] Amianto, F., Abbate-Daga, G., Morando, S., et al.: Personality development characteristics of women with anorexia nervosa, their healthy siblings and healthy controls: What prevents and what relates to psychopathology? Psychiatry Res., 2011, 187(3), 401-408.

[45] Guillaume, S., Gorwood, P., Jollant, F., et al.: Impaired decisionmaking in symptomatic anorexia and bulimia nervosa patients: a meta-analysis. Psychol. Med., 2015, 45(16), 3377-3391.

[46] Treasure, J., Schmidt, U.: The cognitive-interpersonal maintenance model of anorexia nervosa revisited: a summary of the evidence for cognitive, socio-emotional and interpersonal predisposing and perpetuating factors. J. Eat. Disord., 2013, 1, 13.

[47] Bratman, S.: Orthorexia nervosa. Yoga Journal, 1997. Available from: http://www.orthorexia.com/index.php?page=essay

[48] Dudás, K., Túry, F.: Orthorexia nervosa or healthy food addiction: eating disorder or maladaptive strategy? [Orthorexia nervosa avagy egészségesétel-függőség: evészavar vagy maladaptív stratégia?] In: Evészavarok és testképzavarok. (Eds.: Túry, F., Pászthy, B.) Pro Die Kiadó, Budapest, 2008, 53-63. [Hungarian]

[49] Pope, H. G. Jv., Katz, D. L., Hudson, J. I.: Anorexia nervosa and "reverse anorexia" among 108 male bodybuilders. Compr. Psychiatry, 1993, 34(6), 406-409.

[50] Szabó, P.: Special aspects of body image disorders: body dismorphic disorder, plastic surgery and apotemnophilia. [A testképzavarok néhány speciális vonatkozása: testdiszmorfiás zavar, plasztikai sebészet és apotemnofilia.] In: Evészavarok és testképzavarok. (Eds.: Túry, F., Pászthy, B.) Pro Die Kiadó, Budapest, 2008 , 93-109. [Hungarian]

[51] Konstantakopoulos, G., Varsou, E., Dikeos, D., et al.: Delusionality of body image beliefs in eating disorders. Psychiatry Res., 2012, 200(2-3), 482-488.

[52] Tényi, T.: Rare psychiatric symptoms and disorders. [Ritka pszichiátriai tünetek és szindrómák.] Animula, Budapest, 2009. [Hungarian]

[53] Klein, C. A., Hirachan, S.: The masks of identities: who's who? Delusional misidentification syndromes. J. Am. Acad. Psychiatry Law, 2014, 42(3), 369-378.

[54] Tchanturia, K., Morris, R. G., Anderluh, M. B., et al.: Set shifting in anorexia nervosa: an examination before and after weight gain, in full recovery and relationship to childhood and adult OCPD traits. J. Psychiatr. Res., 2004, 38(5), 545-552.
[55] Sifneos, P. E.: The prevalence of 'alexithymic' characteristics in psychosomatic patients. Psychother. Psychosom., 1973, 22(2), 255-262.

[56] Dakanalis, A., Gaudio, S., Serino, S., et al.: Body-image distortion in anorexia nervosa. Nat. Rev. Dis. Primers, 2016, 2, 16026

[57] Zucker, N. L., Merwin, R. M., Bulik, C. M., et al.: Subjective experience of sensation in anorexia nervosa. Behav. Res. Ther., 2013, 51(6), 256-265

[58] Keizer, A., Smeets, M. A., Dijkerman, H. C., et al.: Tactile body image disturbance in anorexia nervosa. Psychiatry Res., 2011, 190(1), 115-120.

[59] Crucianelli, L., Metcalf, N. K., Fotopoulou, A., et al.: Bodily pleasure matters: velocity of touch modulates body ownership during the rubber hand illusion. Front. Psychol., 2013, 4, 703.

[60] Keizer, A., Smeets, M. A., Postma, A., et al.: Does the experience of ownership over a rubber hand change body size perception in anorexia nervosa patients? Neuropsychologia, 2014, 62, 26-37.

[61] Eshkevari, E., Rieger, E., Longo, M. R., et al.: Increased plasticity of the bodily self in eating disorders. Psychol. Med., 2012, 42(4), 819-828.

[62] Tsakiris, M., Tajadura-Jiménez, A., Costantini, M.: Just a heartbeat away from one's body: interoceptive sensitivity predicts malleability of body-representations. Proc. R. Soc. B, 2011, 278(1717), 2470-2476.

[63] Moseley, G. L., Olthof, N., Venema, A., et al.: Psychologically induced cooling of a specific body part caused by the illusory ownership of an artificial counterpart. Proc. Natl. Acad. Sci. U.S.A., 2008, 105(35), 13169-13173.

[64] Gaudio, S., Quattrocchi, C. C.: Neural basis of a multidimensional model of body image distortion in anorexia nervosa. Neurosci. Biobehav. Rev., 2012, 36(8), 1839-1847.

[65] Cash, T. F., Deagle, E. A. 3rd.: The nature and extent of bodyimage disturbances in anorexia nervosa and bulimia nervosa: a meta-analysis. Int. J. Eat. Disord., 1997, 22(2), 107-125.

[66] Hagman, J., Gardner, R. M., Brown, D. L., et al.: Body size over estimation and its association with body mass index, body dissatisfaction, and drive for thinness in anorexia nervosa. Eat. Weight Disord., 2015, 20(4), 449-455.

[67] Denny, B. T., Kober, H., Wager, T. D., et al.: A meta-analysis of functional neuroimaging studies of self- and other judgments reveals a spatial gradient for mentalizing in medial prefrontal cortex. J. Cogn. Neurosci., 2012, 24(8), 1742-1752.

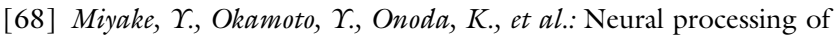
negative word stimuli concerning body image in patients with eating disorders: an fMRI study. Neuroimage, 2010, 50(3), 1333-1339.

[69] McAdams, C. J., Krawczyk, D. C.: Who am I? How do I look? Neural differences in self-identity in anorexia nervosa. Soc. Cogn. Affect. Neurosci., 2014, 9(1), 12-21.

(Ábrahám Ildikó dr., Budapest, Bókay u. 53., 1083 e-mail: abraham.ildiko@med.semmelweis-univ.hu)

\section{Ars longa, vita brevis. (A művészet örök, az élet rövid.)}

